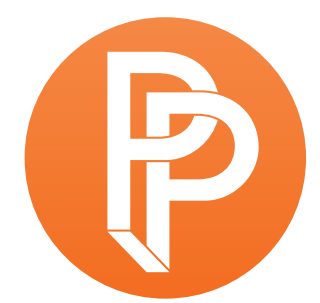

PERFORMANCE

PHILOSOPHY

\title{
“A WORK OF ART DOES NOT CONTAIN THE LEAST BIT OF INFORMATION': DELEUZE AND GUATTARI AND CONTEMPORARY ART ${ }^{1}$
}

\author{
STEPHEN ZEPKE INDEPENDENT RESEARCHER
}

Any attempt to understand Deleuze and Guattari's relation to contemporary artistic practices is immediately confronted with the highly variegated and dispersed field of contemporary art. Nevertheless, there are three aspects of contemporary art that Deleuze and Guattari (in their work both together and alone) directly respond to: 1) the central position of photography, both conceptually and practically; 2) the unavoidable ubiquity of digital technology; 3) Duchamp's readymade and the 'conceptual turn,' or what is also known as postconceptual practice. By following, and sometimes anticipating Deleuze and Guattari's response to these axioms we will be able to extrapolate some of their views on art today. Additionally, this will allow us to construct some alternative art histories accounting for these aspects of contemporary artistic practices, genealogies that while often beginning in familiar places (photography, Duchamp, Benjamin) develop these in unexpected directions that often sit uncomfortably with our usual understandings of contemporary art. We set off, in other words, towards a minor contemporary art.

In Logic of Sensation Deleuze claims that too many people mistake a photograph for a work of art because a photograph cannot-by definition-be art. To think that a photograph is a work of art is not, in other words, a question of taste, it is an ontological mistake. As Deleuze explains, "the photograph tends to reduce sensation to a single level, and is unable to include within the sensation the difference between constitutive levels" (Deleuze 2003, 91). The single level is that of representation, which imposes on sensation its conditions of possible experience, the a prioris of space and time, subject and object, and human consciousness. It is in this sense that the 
photograph is a cliché, and a particularly virulent and ubiquitous one, because photographs are "not only ways of seeing" Deleuze writes, with reference to John Berger perhaps, but "they are what is seen, until finally one sees nothing else" (Deleuze 2003, 91). ${ }^{2}$ Photography's ways of seeing are figurative and narrative, and as what is seen photography enforces our contemporary representational "conventions," or "code" (Deleuze 2003, 91) acting as our conditions of possible experience. We not only see photographs, but rather photography imposes the cliché of the representational image of thought upon us. As a result, 'photography' becomes a kind of shorthand for Deleuze and Guattari, indicating the negative affects of the representational image of thought, and as such they use it as a general term of abuse. Psychoanalysis is condemned for taking "photos" of the unconscious, as is linguistics for doing the same to language (Deleuze and Guattari 1987, 13), Cuvier's "discontinuous photographs" of morphogenesis are rejected (Deleuze and Guattari 1987, 48), ethnologists are abused who "take snapshots of their primitives" (Deleuze and Guattari 1987, 429), and the limits of science are described as the "freeze-frame" it applies to movement (Deleuze and Guattari 1994, 118). All of these examples derive from Deleuze's association (following Bergson) of photography with science's spatialization of time, a philosophical homogenization of any ontology of difference. In this way, photography reveals its political implications because, Deleuze claims, by removing any vital force from the image it "forces upon us" a "truth" that is both "implausible" and "doctored" (Deleuze 2003, 91), thereby establishing and enforcing our "civilization of the cliché" (Deleuze 1989, 21). As a cliché then, the problem with photography is cognitive, political and ontological before it is artistic, and as such Deleuze's criticisms of photography form part of a wide-ranging political analysis of our age of mechanical reproduction that will encompass, as we will see, both the rejection of Conceptual art in What Is Philosophy?, and the significant reservations regarding the "electronic-image" expressed in Cinema 2. ${ }^{3}$

In arguing that the photographic cliché epitomizes the representational image of thought, Deleuze not only attacks photography as a medium, but highlights the dangers of art employing strategies that are ontologically complicit. Art doing so is of course a historical fact, and is implicit in not only the emergence of photography, but the adoption of new digital mediums and the turn to the concept. In all these cases art abandons its medium specificity (Deleuze is especially committed to painting and cinema) and utilizes image-making technologies that are widespread in what we could call the realm of "non-art". Deleuze and Guattari's 'Modernism' in this respect makes a medium's ontological potential a condition of its political effectiveness, and means that many artistic attempts at political intervention are counter-productive as long as they share the representational conditions of possibility of what they critique. In this way the ubiquitous strategies of irony and parody are complicit, Deleuze claims, because "even the reactions against clichés are creating clichés" (Deleuze 2003, 89). Photography, Conceptual art, the nascent digital culture Deleuze saw in the "electronic-image" (as we shall see), post-modern irony and critical political art all share this fundamental problem, they remain on the level of representation and so are, he says, "too intellectual" (Deleuze 2003, 87). A quick look at a recent account of contemporary art by Peter Osborne perhaps provides an explanation of this strange comment. Contemporary art is "postconceptual," Osborne claims, because since the conceptual turn of the late-60s all art is conceptually determined, and so makes use of a "post-aesthetic poetics" (Osborne 2013, 33). 
Contemporary art is defined, Osborne argues, by: 1) its ongoing conceptual and critical antagonism towards its aesthetic heritage; 2) its break with art's historical mediums epitomized by photography; 3 ) its integration of the avant-garde into the culture industry; 4) its spatio-temporally distributed unity enabled by digital technology; 5 ) its ability to transcend locality through the transnational circuits of commodity exchange. Together these aspects have led to what Osborne calls the "ontological mutation" of postconceptual art, which has "exposed the aesthetic misrecognition of the art work as an ideological fraud" (Osborne 2013, 50). Osborne considers postconceptual art's immanence with the cognitive and technological conditions defining our present as the condition of possibility for its political resistance. But this is precisely what Deleuze and Guattari reject, seeing the way art has adopted our contemporary image of thought as its complicity and compliance. This is why Deleuze condemns contemporary artistic practices for being "too intellectual," while he does want art to be immanent in contemporary life it should be so only as its outside, as its undetermined aesthetic excess, as-and it's a nice phrase that comes from Osborne-its "ruptural futurity". We'll see what this means soon enough, but it will certainly involve re-thinking the role of 'thought' in contemporary art, and as is already obvious this will run very much against how contemporary art has developed over the last 50 years.

At the core of this disconnect between Deleuze and Guattari and contemporary art is their insistence on Kant's discovery in the third Critique that aesthetic experience-and more exactly the sublime-escapes the limits placed upon it by the concepts of the understanding and directly expresses transcendental and differential Ideas. Deleuze bases his own aesthetics on this moment, which rips apart the veil of representation in an explosion of the real. Indeed, Deleuze and Guattari's descriptions of art often culminate in such an explosion; Turner's canvases in AntiOedipus, the homemade atomic bomb of the artisan-artist in A Thousand Plateaus, the hysterical scream of paint in Francis Bacon, the final eruption in Rossellini's Stromboli in Cinema 2, or indeed the explicit connection of rhythm to the sublime in the seminars on Kant. As Deleuze so memorably puts it there, and his tone is entirely approving: "My whole structure of perception is in the process of exploding" (Deleuze 1978, 13). That, to put it simply, is what Deleuze sees as the "political" power of art, it destroys the representational image of thought. Obviously this is a strange kind of "ontological politics" that is not oriented around political issues or positions, and Deleuze and Guattari make it clear that art does not, and should not operate in this way. In What Is Philosophy? they suggest that revolution is the "presentation of the infinite in the here and now" (Deleuze and Guattari 1994, 100), which is what art can do even if it cannot "summon a people" who might effect a revolution. "A people can only be created in abominable suffering" they say, "and it cannot be concerned any more with art or philosophy" (Deleuze and Guattari 1994, 110). But although art cannot make "real politics" in this sense, it can create sensations that resist "servitude," "shame," the "intolerable" and the "present" by creating new bonds between people, which are the "victory of a revolution [...] even if these bonds last no longer than the revolution's fused material and quickly give way to division and betrayal" (Deleuze and Guattari 1994, 177). This would be the sense of a transversal revolutionary politics, not that art and political movements somehow work together-as with leftist art activism that sees itself as the "aesthetic wing" of a militant movement (see, Raunig 2007)—but that they each pursue revolution with the means at their disposal, which in art's case is aesthetic, the sensation. 
Art, then, can cause explosions that destroy the structure imposed upon perception by the understanding (i.e., conceptually organized cognition), and its representational image of thought (most significantly, recognition). This would be art's politics, to explode the representational clichés that dominate our thought and sight, and to offer alternatives to the underlying cognitive structure that supports this. This is precisely how Bacon uses photographs, he extracts their abstract qualities such as texture and ignores their representational clichés of figuration and narrative. This typifies, Deleuze claims, "the most interesting cases" of painting using photography, which "are those where the painter integrates the photograph, or the photograph's action, apart from any aesthetic value" (Deleuze 2003, 183). In these cases painting uses the photograph in order to betray both its representational and aesthetic functions (understood here as being integrated in normal aesthetic experience, as Kant outlines in the first Critique) ${ }^{4}$ In this way Bacon's painting unites Kant's two Critiques on the aesthetic by making what exceeds the limits of the first (sensation) come to define the scope of the third (art), as it confronts its immanent conditions of representation that its photographic sources embody, and so confronts the political conditions by which they constrain the present. This is also the case in Deleuze's account of certain paintings by Gerard Fromanger, who projects banal photographs of shops onto his canvas and then paints them in monochrome colors. In this way, Deleuze argues, the paintings conflate the representational structure of the photograph with the abstraction of the commodity on the flat plane of the painting, which thereby actualizes "the circulation of exchange value, whose importance lies in its mobilization of indifferents" (Deleuze 1999a, 72). Fromanger puts this "circuit of death" into relation with the scintillating energy of the painting's colors, converting it into a "vital circuit" (Deleuze 1999a, 74) between the commodities the photo represents and the paint and its sensation. In this way the abstract and yet differential force of colour disrupts capitalist circulation, just as photography overcomes its own limits by becoming painting. ${ }^{5}$ As Deleuze puts it: "This circuit of life feeds continually on the circuit of death, sweeps it away with itself to triumph over it" (Deleuze 1999a, 73). While this does not accomplish a political revolution, it is revolutionary.

Bacon gives a clear explanation of his "non-rational" thought process in his interviews with David Sylvester. Speaking of his own technique he says;

the mystery of fact is conveyed by an image being made out of non-rational marks.
And you can't will this non-rationality of the mark. That is the reason that accident
always has to enter into this activity, because the moment you know what to do,
you're making just another form of illustration. (Sylvester 1987, 58)

What is this "mystery of fact"? The fact that a sensation created by an art work doesn't remain on one level-like abstract art or photography—but appears, Bacon continues, "on many levels" and so "leads to a deeper sense of the reality of the image," a reality "caught raw and alive" (Sylvester $1987,66)$. Here the sensation or 'fact' emerges through overcoming the representational and narrative clichés that are not simply produced by, but actually constitute rational consciousness. The sublime intuition frees the nervous system from its conceptual determination, forcing the brain to confront chaos and construct an analogical expression of it. Deleuze described this 
sublime faculty of 'thought' in Difference and Repetition, and as we shall see it is a model that he uses to the end, even if its vocabulary changes.

While Deleuze argues that Bacon and Fromanger use the photograph against itself, his analysis of cinema is not so generous. The very ontology of cinema, its essence as movement- and time-image is founded on not being photography. The cinematic "shot," Deleuze writes in Cinema 1, is a "mobile section," a "temporal perspective" on the whole of duration, a perspective whose modulating vitality effectively keeps this whole open. The photograph, on the other hand, is an "immobile section" that "moulds" the internal forces of a thing into equilibrium, forcing it to become an object, or in other words a representation (Deleuze 1986, 24). Deleuze attributes his understanding of cinema to Henri Bergson, and follows him in distinguishing "real movement" expressing "concrete duration" from the "immobile sections" that represent units of "abstract time" (Deleuze 1986, 1). Abstract time separates an object from the space it moves through, spatializing movement and dividing it up into homogeneous units, while 'real' movement is heterogeneous-even with itselfinasmuch as it changes qualitatively each time it is divided. This is the first, and most famous of Bergson's three theses on movement, but it immediately gives rise to a fundamental difficulty when applied to cinema, which is that Bergson himself seems to refute it. In Creative Evolution, written in 1907, Bergson attributes what Deleuze calls the "incorrect formula" (Deleuze 1986, 1) for time to cinema. "What is real," Bergson writes, "is the continual change of form: form is only a snapshot view of a transition" (Bergson 1944, 328). The "cinematograph," he continues, throws a series of such "instantaneous views," or snapshots on a screen "so that they replace each other very rapidly". In this way, Bergson argues, cinematic projection reconstructs movement from photographs (Bergson 1944, 331-332), meaning that the movement seen on the screen is not in the image but in the cinematic "apparatus". Movement is in this way rendered abstract and impersonal, and, Bergson writes: "Instead of attaching ourselves to the inner becoming of things, we place ourselves outside them in order to recompose their becoming artificially" (Bergson 1944, 332). This, Bergson will claim, is nothing less than an image of thought, because as he puts it, "we take snapshots of the passing reality [...] hardly doing anything else than setting going a kind of cinematograph inside us" (Bergson 1944, 332). The brain is a cinema projector replacing photos with more photos, representing movement in a pre-existing space by stringing together snapshots and preventing us from experiencing the non-rational 'fact' of a movement's duration. Deleuze makes various excuses for Bergson's 'mistake,' and makes him instead the originator of the idea that the essence of cinema is the moving image simultaneously expressing and constructing the infinite movements of duration. In this sense "the brain is the screen" Deleuze will say (see Deleuze 2006, 282), rather than the photographic projector, affirming that technology supports and extends our image of thought, and so plays a crucial role in the politics of our contemporary imageculture.

The movement-image, however, only indirectly expresses the becoming of the open whole of duration because it passes through the sensory-motor schema of the viewer, and so makes subjective interest and value its condition of possibility. Indeed, at the beginning of Cinema 2 Deleuze dramatically dismisses the movement-image as a cliché (Deleuze 1989, 20), one that continually moves towards its sublime limit but can never break through to its immanent outside, 
can never provide a real experience that might encompass the all, and climb the thread suspending this moment from the universe. The movement-image, he says, is too "normal" (Deleuze 1989, 36) because it subordinates the movement of the whole to the conditions determining its possible representation. It is as if the movement-image brings us back to a disappointingly transcendental subject, the brain of the human-all-too-human cinema-goer who cannot escape the assumption that the universe is in some way for us. Modern cinema will invent a far more astringent and alienating cinema where the viewer will be replaced by the visionary, and the cliché imposed by the sensory-motor will explode in what Deleuze, again entirely approvingly, calls "abnormal" and "aberrant" films.

The time-image of modernist cinema abandons narrative and the normal relations of subjects and objects in its embrace (at least on Deleuze's account) of total experimentation. This too, will be an image that emerges against photography, and even perhaps through its negation. For example, Deleuze will argue that while Ozu's use of extremely long takes or 'still-lives' perhaps suggests a reconciliation of cinema and photography, in fact the opposite is the case and "[a]t the point where the cinematographic image most directly confronts the photo, it also becomes most radically distinct from it" (Deleuze 1989, 17). Why? Because in Ozu's still-life we are confronted with time in its pure state, and here Deleuze recites the formula that he's used since the last chapter of his book on Proust: "There is becoming, change, passage. But the form of what changes does not itself change, does not pass on. This is time, time itself, 'a little time in its pure state': a direct time-image, which gives what changes the unchanging form in which the change is produced" (Deleuze 1989, 17). This passage also clearly echoes that from Difference and Repetition where Deleuze explains the third synthesis of time, and how it marks an explosion of the sun that definitively overcomes any transcendental subjectivity-and more specifically its a priori principle of chronological timeestablished by Kant's Copernican Revolution. At this sublime moment-Deleuze specifically calls it such (Deleuze 1994, 146) ${ }^{6}$-aesthetic experience exceeds its conditions of possibility and senses the transcendental Ideas, which on Deleuze's perversely Nietzschean reading of Kantian critique emerge as the differential, real and immanent conditions of experience itself. At this sublime moment transcendental experience (i.e. Ideas), or "problems" as Deleuze calls them, emerge in a Geistesgefuihl (as Kant calls the sublime), an "intellectual-feeling" or feeling-thought. This strange sensation presents the unpresentable, it comprehends infinity in 'thinking' the Idea, and as a timeimage it puts the supersensible and sensible, virtual and actual into a relationship of reciprocal determination. In Difference and Repetition Deleuze calls this the "secret coherence" of the event and the act, a coherence that turns back against the transcendental subjectivity that gave birth to it to "smash it to pieces" (Deleuze 1994, 89). This, Deleuze tells us with some satisfaction, is the precise moment within Kantianism when Kant destroys his own system, "a furtive and explosive moment which is not even continued by Kant" (Deleuze 1994, 58). This sublime moment, or event, is thought. "To think," Deleuze writes, "is to create-there is no other creation-but to create is first to engender 'thinking' in thought" (Deleuze 1994, 147). The syntheses constituting rational experience, not only Kant's but those of the movement-image as well, are thereby replaced by "spatio-temporal dynamisms," as Deleuze calls them in Difference and Repetition, or by the refrains that Deleuze and Guattari say replace time as "the ground in a priori synthetic judgment" (Deleuze 
and Guattari 1987, 378-9), or what in cinema Deleuze calls the "vital intuition" of the time-image (Deleuze 1989, 22).

Despite Deleuze's celebration of the sublime time-images produced by Modernist cinema in Cinema 2, "the brain is the screen" also has a dark side, and is also responsible for the worst aspects of our control society. Deleuze here returns to his theme of how a vital art resists its political exploitation and oppression, and the quixotic heroism of what he and Guattari call art's "unfortunately incomparable, but nevertheless competitive, means" (Deleuze and Guattari 1987, 381). When the brain becomes the screen a new mechanism producing subjectivity emerges in the ambiguous figure of the "spiritual automaton". This passive viewer is on the one hand animated by all the spectacular clichés of our utterly mediated control society, and on the other is a visionary schizo synthesizing exterior forces through an inhuman nervous intelligence. The politics of the brain-screen involves a struggle over this power of "psychomechanics," a conflict between the State and corporate mechanisms that automate our thought and thereby homogenize subjects into masses, and the singular and ontogenetic event produced by a 'will to art'. This is a political struggle over the production of subjectivity, and while art uses technology to produce an undetermined singular subjectivation, digital technology in the hands of capital imposes its immanent conditions of possibility in order to, Deleuze claims, reproduce "extrinsic elements [...] in an autonomous manner by the intrinsic elements of the code" (Deleuze 2003, 114). Significantly, Deleuze praises Benjamin's The Work of Art in the Age of Mechanical Reproduction for offering an immanent critique of this development. Benjamin, he says, set himself

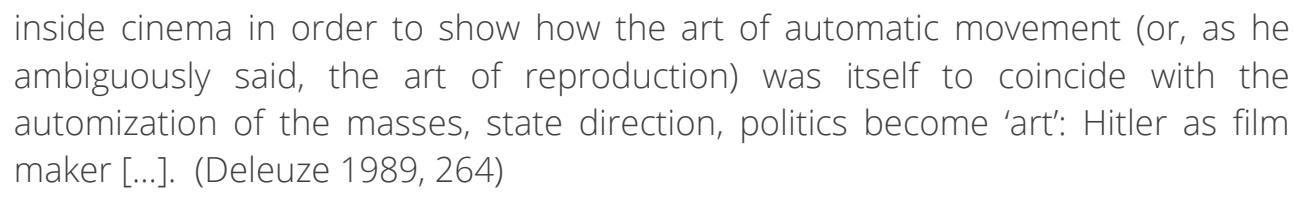

Benjamin foresaw the aestheticization of politics that was made possible by the replacement of artistic singularity, or "aura" as Benjamin calls it, by mass reproduction. Against the usual interpretation of Benjamin then, Deleuze sees this as a largely negative development because it institutes a new regime of production reproducing resemblances on a mass scale, and introduces a new control society operating through the 'psychomechanics' of consumption and conformism, a regime he rather dramatically summarizes (following Benjamin) as "Hitler and Hollywood, Hollywood and Hitler" (Deleuze 1989, 164).

Deleuze discusses this conflict in relation to the electronic-image, which emerges from "a new computer and cybernetic race, automata of computation and thought, automata with controls and feedback" (Deleuze 1989, 265). Here power is no longer organized around the Führer, but is instead "diluted in an information network" (Deleuze 1989, 265) that not only effects the story-line of cinema (as computers become characters, as in Alphaville or 2001), but the form of its images. While the electronic-image is able to express duration like the time-image, in doing so it also extends technological and political control beyond the limits of space and time, and out into the infinite. According to Deleuze the electronic-image has no outside, it has a right side and a reverse, and is reversible and non-superimposable. This enables it to be the object of perpetual reorganization or 
constant variation within an omni-directional space, these variations being ordered through axiomatics that remain tied to representational clichés on the one hand, and to the circulation of capital on the other. Under these conditions the (brain) screen has become, Deleuze claims, using a term he takes from the art-historian Leo Steinberg, a "flat-bed plane," a "table of information, an opaque surface on which are inscribed 'data,' information replacing nature, and the brain-city, the third eye, replacing the eyes of nature" (Deleuze 1989, 265). These aspects of the electronic-image, it is important to note, are no longer specific to the cinema, but condition all aspects of image production, and inasmuch as they are co-extensive, all aspects of life in general. The political stakes of the electronic-image are therefore those of contemporary life, and revolve around the status of thought; what in this flat brain-screen of the electronic-image is creative, and what exercises control? What, in other words, is the relation between the "new spiritual automatism" and the "new psychological automata," are we entering an age of "cerebral creation or deficiency of the cerebellum?" (Deleuze 1989, 266)

Deleuze is at his most uncertain here, and is clearly reluctant to speculate very far about an image regime that was still embryonic. ${ }^{7}$ While he says the question remains that of expressing a new "will to art," the stakes seem to have risen; "I am afraid that the new methods may invalidate all will to art, or make it into a business, a pornography, a Hitlerism" (Deleuze 1989, 266). Nevertheless, the clues for creating a new future seem to lie in the past, inasmuch as "the cinematographic image was already achieving effects which were not those of electronics, but which had autonomous anticipatory functions in the time-image as will to art" (Deleuze 1989, 266). Bresson, he tells us, first reveals how modern psychological automata are produced by the speech act rather than motor action. This is then picked up by Robbe-Grillet's strange deconstructions of genre, where repetition and flat intonation suggest the characters are hypnotized, as if their actions were pre-ordained by the genre's form. Similarly, Resnais' films reveal an automation achieved through the unpredictable feedback systems operating between past and present. These anticipations of aspects of the electronic-image in the time-image created remarkable images and new sensations, but while they reveal the creative potentials of the Modernist will-to-art they also illustrate how quickly these are instrumentalized by the powers that control their production.

This is because, Deleuze argues, the brain-screen is not defined by its technology but "depends on an aesthetic" (Deleuze 1989, 267). It is a question, in other words, of how perception is ordered and controlled, of the contemporary conditions of possible experience, and today it is the aesthetic of the "flat-bed plane" that organizes images into information regardless of whether the technological support is digital or analog. Deleuze's perceptive description in fact applies as well to postCinematic images as it does to the screen-prints of Robert Rauschenberg;

\footnotetext{
the image is constantly being cut into another image, being printed through a visible mesh, sliding over other images in an 'incessant stream of messages,' the shot itself is less like an eye than an overloaded brain endlessly absorbing information: it is the brain-information, brain-city couple which replaces that of eyeNature. (Deleuze 1989, 267)
} 
The problem is that the brain-screen has no outside, it encompasses the world in a continual variation that nevertheless tends to be organized by a limited number of (aesthetic) axioms. These axioms organize life in general rather than just the human, and in this sense, Deleuze explains, "free life within man himself" (Deleuze 1999b, 130). The form of man has been "overcome" in the realms of language, life and labour, Deleuze argues, but rather than this liberating man it has dissolved him, as life regroups on dispersal, on an "unlimited finity" where "a finite number of components yields a practically unlimited diversity of combinations" (Deleuze 1999b, 131). While on the one hand this unlimited finity is the contemporary form of the "eternal return" (Deleuze 1999b, 131), it is also the moment when the vital power of life itself can be captured by technology and capital. It is no longer, in other words, a question of discovering inhuman forces within the human, because the contemporary is marked by these forces relocating to an asignifying language (Deleuze 1999b, 132), to molecular biology and its manipulation of the genetic code, and to "third generation machines, cybernetics and information technology" (Deleuze 1999b, 131). How can "cerebral creation" liberate our brains, when the creative energy of "life" is no longer opposed to the political systems that profit from it, but is entirely immanent within them? Deleuze's last line of the book on Foucault ruefully hopes that this "will not prove worse" than previous regimes, although in the essay Postscript on Control Societies this seems unlikely, as he balefully warns "[a] snake's coils are even more intricate than a mole's burrow" (Deleuze 1995, 182).

This would explain the ambivalence of Deleuze's positive example of an electronic-image-HansJürgen Syberberg's film Hitler: A Film from Germany, which he offers as an antidote to Benjamin's warning of Hollywood becoming equivalent to Hitler. This film, Deleuze claims, is the sequel to Kracauer's famous book From Caligari to Hitler because it runs in the opposite direction, not from German film to Hitler, but from Hitler to A Film from Germany. As a result, the film effects a "change taking place inside cinema, against Hitler, but also against Hollywood, against represented violence, against pornography, against business..." (Deleuze 1989, 264) It does so on the level of content through a critique of the fascist psychological automaton, of the production of "Hitler in us". On the level of form however, Syberberg's electronic-image-its connectivity, its flatness and its informative nature-is constructed through older redundant technologies that the movementimage had itself discarded and ignored. Thus Syberberg's celebrated use of back and front projection, of models and puppets, or of miming to playback all, according to Deleuze, use these techniques in ways that Hitler and Hollywood had already rejected or perfected (Deleuze 1989, 264). Such techniques are therefore immanent to but already distanced from the powers they critique, enabling them to grasp the contemporary electronic-image from within in order to pull it apart through their disjunctions and disassociations (Deleuze 1989, 267), a process culminating in the disjunctive synthesis of sound and image, "a fusion of the tear," as Deleuze quotes Syberberg (Deleuze 1989, 268). In this way Syberberg's films,

stretch out a vast space of information, like a complex, heterogeneous, anarchic space where the trivial and the cultural, the public and the private, the historic and the anecdotal, the imaginary and the real are brought together [in ...] a network, in kinds of relationship which are never those of causality. (Deleuze 1989, 268-269) 
This is a contemporary electronic-image, but it is a mad, non-representational, non-linear, "irrational" and utterly schizophrenic image (Deleuze 1989, 268). Significantly, it is the division of sound and image that imparts "a non-totalizable complexity" to the experience of the film's 'information' that goes beyond "the psychological individual" (Deleuze 1989, 269). The problem however, is that Syberberg's sublime "will to art," his "art beyond knowledge" and his "creation beyond information" seeks to redeem the mythical power of the speech act, "an act capable of creating the myth instead of drawing profit or business from it," and redeem its subject, "a pure informed person capable of emerging from the debris" (Deleuze 1989, 270). This seems a reactive politics that means, Deleuze laments: "Redemption arrives too late [...]: it appears when information has already gained control". Contemporary art in the time of the electronic-image is perhaps always too-late in this sense, because like cinema, its "life or the afterlife" also "depends on its internal struggle with informatics" (Deleuze 1989, 270). In this struggle on the inside (of capitalism, of informatics) all contemporary art can do is reflect on its conditions of possibility, and try to ask, Deleuze says, "a question that goes beyond them" (Deleuze 1989, 270). Such a question would, as Deleuze puts it, "convert a hostile area to art, with a certain violence, and of turning means against themselves" (Deleuze 1989, 331). But the problem, as we have seen, is that an area "hostile" to art shares the same aesthetic as art employs to go beyond it. The electronic-image, unlike the time-image perhaps, defines both the means of control and the means to its resistance.

Unsurprisingly, the snake's coils also embrace contemporary art, and in What Is Philosophy? Deleuze and Guattari will return to the "flatbed plane" in their rejection of Conceptual art, claiming that with it the composition of the image has become "informative" rather than energetic, and the opinion of the viewer rather than sensation defines what is art (Deleuze and Guattari 1994, 198). We see here a similar shift in the conditions of artistic production to what Deleuze described in the case of cinema, with the "conceptual turn" art starts to share its aesthetic "diagram" with the rest of life, which now wants to produce a "concept". Contemporary art therefore risks becoming the mere "propagation of information" in an era when, Deleuze says, "information is exactly the system of control" (Deleuze 2006, 320-321). Deleuze could not be any more explicit in his condemnation of this development, declaring: "A work of art has nothing to do with communication. A work of art does not contain the least bit of information" (Deleuze 2006, 322). In these terms both the electronic-image and post-conceptual artistic practices risk becoming complicit with established political powers, by adopting, Deleuze warns in Cinema 2, their "operational processes" and becoming "caught in the machine's operations and passage" (Deleuze 1989, 331). In this situation, he argues, so-called 'critical' practices achieve nothing, because the production of "counterinformation" actually enforces conformity by failing to go beyond the existing conditions of possibility, or format, that underlies all "intelligence" (see Deleuze 2006, 322). But because these conditions have seemingly joined with the powers of life to take us beyond the form of man, as Deleuze laments in Foucault, it is hard to see how any such 'beyond' might be possible.

This then, is the situation confronting visual art today, inasmuch as post-conceptual artistic practice is generally taken to mean that contemporary art, no matter how aesthetic, is nevertheless organized through a conceptual framework. The model for this form of practice comes from Marcel Duchamp, who tells us in The Green Box (1935) that the readymade is a photographic "snapshot" or 
"sign of accordance" between it and the laws governing its choice (Duchamp 1973, 27-28). It's no surprise then, that Duchamp hated Bergson. For Duchamp, this choice is entirely independent of the readymade object, which merely exists as "information" (Duchamp 1973, 32) indicating that a conceptual decision has taken place-'this is art'. This 'decision' not only liberates art from any medium specificity, but from any aesthetic conditions at all, involving as Duchamp famously put it "a complete anaesthesia" (Duchamp 1973, 141). Art was no longer a question of color and materials, but, as Duchamp rather wryly put it, of 'grey matter' and of the concept of art that it instantiated. The art object becomes a simple place-holder for the concept of art, an entirely arbitrary signifier that effectively dematerializes its signified-'art'.

In A Thousand Plateaus Deleuze and Guattari will offer an alternative understanding of the readymade that explores an entirely different sense of how 'thought' might produce art. There, they claim that "[t]erritorial marks are readymades," (Deleuze and Guattari 1987, 349, see also Deleuze and Guattari 1994, 184) using the English word 'readymade' in order to emphasize its connection to Duchamp (see Deleuze and Guattari 1980, 389; 1991, 174). The fundamental artistic gesture of the readymade, Deleuze and Guattari argue, is the appropriation of something in order to use it in a completely different way, like the stage-maker bird that turns over fallen leaves to mark out the 'stage,' on which it sings "a complex song made up from its own notes and, at intervals, those of other birds that it imitates". In this the stage-maker bird is, Deleuze and Guattari say, a "complete artist" (Deleuze and Guattari 1994, 184). This makes the readymade, they continue, "the base or ground of art. Take anything and make it a matter of expression" (Deleuze and Guattari 1987, 349). In this sense the readymade is a technique used to create a refrain, a material object that expresses (ie., repeats) a genetic difference. In the case of the stage-maker bird, it both establishes a territory and opens it onto its outside, because the maintenance of one involves the necessity of the other, just as the present draws from the past in order to create its future. The refrain, in this sense, expresses a spatio-temporal dynamism. "As though," Deleuze and Guattari write, "the circle tended on its own to open onto a future as a function of the working forces it shelters" (Deleuze and Guattari 1987, 343). If the functional purpose of this 'artwork' is to perpetuate the species, its aesthetic dimension introduces "lines of drift" as Deleuze and Guattari put it, that free it from its conditions (Deleuze and Guattari 1987, 344). Perhaps then, this model of the readymade might be able to ask a question that goes beyond its ubiquitous acceptance as the model of 'conceptual' art.

In one sense Deleuze and Guattari's reading of the readymade is familiar, inasmuch as it makes the simple gesture of appropriation the fundamental creative act, and is entirely consistent with Duchamp's quip that a readymade is simply an object that has "changed direction". It is a change in direction that is also achieved by Bacon's "catastrophe," which opens the conditions of painting onto their outside and allow chaotic forces to act as what Deleuze and Guattari call "directional components," or the "ecstasies" of "chaosmosis" (Deleuze and Guattari 1987, 345). Unlike Duchamp however, Deleuze and Guattari see the change in direction achieved by the readymade to be material and aesthetic, rather than conceptual, and as such it is an example of what they call 'thought'. This non-conceptual thought is thought as passive synthesis, as the sublime event of a problematic Idea creating its intuition (to return to Deleuze's vocabulary from Difference and 
Repetition), and is how the readymade escapes mechanical reproduction and restores, Guattari tells us, "the Benjaminian aura" (Guattari 2013, 209). Here we have the beginning of a genealogy of contemporary artistic practice that incorporates the readymade as its foundational moment, but rather than being post-conceptual involves, instead, producing material sensations through a sublime thought. It is here, perhaps, that we have a question that might go beyond the reservations Deleuze expressed about Syberberg's films, one that emerges from the material conditions of the new aesthetic of the electronic-image, while refusing to 'return' to the old technologies that predate it. It would not be a question of redeeming painting in this sense, but of posing a question to contemporary 'thought' that goes beyond its current and conditional aesthetic. This would be to go beyond the definition of contemporary art as postconceptual and post-internet, and to seek once again the real conditions of its difference. ${ }^{8}$

Guattari discusses Duchamp's first readymade, the Bottle Rack (1913), precisely in this sense. The act of appropriation, Guattari writes, can produce a "problematic Affect" (Guattari 2013, 206) (what Deleuze calls passive synthesis), in which various components suddenly appear together without obvious subjective intention or meaning. This problematic Affect is a chaotic incursion or "event" that "speaks through me" and "devalues the clarities and urgencies which imposed themselves on me" and "makes the world sink into a void which seems irremediable" (Guattari 2013, 205). This is the moment of intensity=0, which Deleuze often refers to and that he draws from Kant's first Critique. There, Kant argues that sensation emerges as an intense difference from 0 , and Deleuze and Guattari will return to this definition of sensation throughout their work. On the one hand, then, the Bottle Rack voids its context and received meaning, intensity $=0$, and on the other, Guattari writes, it "functions as the trigger for a Constellation of universes of reference that sets off intimate reminiscences-the cellar of the house, a certain winter, beams of light on the spider webs, adolescent solitude" (Guattari 2013, 209, translation modified). The Bottle Rack changes direction, and doesn't stop changing direction, or as Guattari puts it, there is a "discordance of different ways of beating time," which are "set into refrains" (Guattari 2013, 206). Beginning from the problematic Affect, from its singular and intimate "feeling of being" (Guattari 2013,213) the readymade produces a "fractal virtualization" as Guattari calls it, from which "procedures of elucidation threaten to flee in every direction" (Guattari 2013, 206). The readymade is first a sublime moment dislocating experience from its conceptual conditions, and allowing it to receive the aleatory forces of the event. This is the moment of intensity $=0$ where intuition is undetermined by the transcendental syntheses of space and time, and is instead able to develop in relation to this immanent outside as a spatio-temporal dynamism or refrain expressing all of time and space from its perspective. This is what Guattari calls the art work's "consummation as disjunction" (Guattari 2013, 211), its rupture with received meaning (cliché) that turns its material expressive, the aesthetic object being both a material body and an image, an actualization of the virtual dimension of duration as well as a thread the readymade's appropriation follows back into this encompassing element of living force. The readymade thus becomes what Guattari calls an "existential refrain" (Guattari 1995, 15), because it expresses the vitality of life, in a life, it always "produces an added value, it secretes a surplus value of code. It is always ready to pull something out of its pocket" (Guattari 2013, 134). The readymade is a "multiplicating" (Guattari 2013, 211) process that produces an aesthetic rupture with representation, while simultaneously actualizing this process in a 
"subjectivation". As a result, the readymade's "mutating becomings" (Guattari 2013, 205) or "heterogenesis" enable the aesthetic object, Guattari claims, to act as a "reappropriation, an autopoeisis of the means of production of subjectivity" (Guattari 1996, 198). The readymade, we might say, is the way contemporary artistic practice accomplishes a resistant form of spiritual automation, deterritorializing subjectivity into its components of molecular matter and cosmic force, and reterritorialising these into a people to come, into, as Deleuze and Guattari so poetically put it, "vectors of a cosmos that carry them off; then the cosmos itself will be art" (Deleuze and Guattari 1987, 381). Thus the readymade demonstrates Deleuze's insistence that Kant's two senses of the aesthetic - as a theory of perception and as a theory of art-must come together. What he means by this is that the reflective aesthetic judgment found in the third Critique must replace the conceptual understanding determining experience as it appears in the first. In these terms, then, what we need is basically the opposite of what Osborne's triumphalist account reports; the hegemony of the concept in a non-aesthetic and post-conceptual art. Instead Deleuze and Guattari call for an aesthetic post-conceptual art, a sublime art that affirms the power of thought to accelerate our cybernetic machines beyond the limits of their current subjectivations qua productions of statistical masses. While Deleuze, when on his own, was clearly worried that this problem might have escaped our means to grasp it, with Guattari he projected the artistic 'thought' of the readymade beyond its conditions of informative representation, digital reproduction and post-aesthetic conceptualism. In affirming a post-conceptual art against the concept Deleuze and Guattari affirm an aesthetic regime whose univocity goes beyond the reach of global capitalism or digital technology, and whose "transindividual subjectivity" (Guattari 1995, 101) sets off towards a new Nature, towards the sci-fi Romanticism of a "cosmic" art.

\section{Notes}

\footnotetext{
1 The quotation in the title comes from Deleuze (2006), 322.

2 "The photo," Deleuze and Guattari tell us in A thousand plateaus, "faciality, redundancy, signifiance, and interpretation are at work everywhere" (Deleuze and Guattari 1987, 116).

${ }^{3}$ Despite this, I think it's also possible to propose examples of "minor photography" that attempt to resist the cliché (for examples, see Bleyen 2012).

${ }^{4}$ As Bacon puts it, "I think the texture of a painting seems to be more immediate than the texture of the photograph, because the texture of the photograph seems to go through an illustrational process onto the nervous system, whereas the texture of a painting seems to come immediately onto the nervous system" (Sylvester 1987, 57-58).

${ }^{5}$ In a less explicitly political way than Fromanger, the painter Florence Julien, "invented," Deleuze and Guattari write, "a procedure by which she extracts from photographs lines that are nearly abstract and formless" (Deleuze and Guattari 1987, 224).

${ }^{6}$ A fact almost never mentioned in the literature, except for the notable exception of Janne Vanhanen's excellent book Encounters with the Virtual: The Experience of Art in Gilles Deleuze's Philosophy (2010).
} 
${ }^{7}$ Deleuze writes: "We do not claim to be producing an analysis of the new images, which would be beyond our aims, but only to indicate certain effects whose relation to the cinematographic image remains to be determined" (Deleuze 1989, 265).

${ }^{8}$ This would be the project of Éric Alliez, between The Brain-Eye, New Histories of Modern Painting which seeks "to bring to light a thinking at work in 'modern painting' (to show that it thinks and how it thinks)" (Alliez 2016, xxi) and Défaire l'image: De l'art contemporain which addresses the more diffuse question of the 'aesthetic' conditions of contemporary artistic practices in the midst of life.

\section{Works Cited}

Alliez, Éric with collaboration from Jean-Clet Martin. 2016. The Brain-Eye: New Histories of Modern Painting. Translated by Robin Mackay. London and New York: Rowman \& Littlefield.

Bergson, Henri. 1944. Creative Evolution. Translated by Arthur Mitchell. New York: Random House.

Bleyen, Mieke, ed. 2012. Minor Photography: Connecting Deleuze and Guattari to Photography Theory. Leuven: Leuven University Press.

Deleuze, Gilles. 1978. Deleuze - Second lesson on Kant, 21 March, 1978. Translated by Melissa McMahon. Accessed September 2016. Available at www.webdeleuze.com

-_- 1986. Cinema 1, The Movement-Image. Translated by Hugh Tomlinson and Barbara Habberjam. Minneapolis: University of Minnesota Press.

1989. Cinema 2, The Time-Image. Translated by Hugh Tomlinson and Roberta Galeta. Minneapolis: University of Minnesota Press.

_-_. 1994. Difference and Repetition. Translated by Paul Patton. New York: Columbia University Press.

. 1995. Negotiations, 1972-1990. Translated by Martin Joughin. New York: Columbia University Press.

_-_. 1999a. "Cold and Heat." In Photogenic Painting/La Peinture Photogénique, edited by Gérard Fromanger, translated by Dafydd Roberts. London: Black Dog Publishing.

___. 1999b. Foucault. Translated by Sean Hand. London: Continuum.

- - - 2003. Francis Bacon: the logic of sensation. Translated by Daniel W. Smith. London and New York: Continuum.

_-_. 2006. Two Regimes of Madness, Texts and Interviews 1975-1995. Edited by David Lapoujade. Translated by A. Hodges and M. Taormina. New York: Semiotext(e).

Deleuze, Gilles, and Felix Guattari. 1987. A Thousand Plateaus, Capitalism and Schizophrenia. Translated by Brian Massumi. Minneapolis: University of Minnesota Press.

___. 1980. Mille Plateaux, Capitalisme et Schizophrénie. Paris: Minuit.

1991. Qu'est-ce que la philosophie? Paris: Minuit.

1994. What Is Philosophy? Translated by Hugh Tomlinson and Graham Burchell. New York: Columbia University Press.

Duchamp, Marcel. 1973. The Writings of Marcel Duchamp. Edited by Michael Sanouillet and E. Peterson. New York: Da Capo.

Guattari, Félix. 1995. Chaosmosis, : An Ethico-aesthetic Paradigm. Translated by Paul Bains and Julien Pefanis. Sydney: Power Publications. 
1996. The Guattari Reader. Edited by Gary Genosko. New York: Blackwell.

2013. Schizoanalytic Cartographies. Translated by Andrew Goffrey. London and New York: Bloomsbury.

Guattari, Félix, and Antonio Negri. 1990. Communists Like Us. Translated by Michael Ryan, New York: Semiotext(e).

Osborne, Peter. 2013. Anywhere or Not At All: Philosophy of Contemporary Art. London: Verso.

Raunig, Gerald. 2007. Art and Revolution: Transversal Activism in the Long Twentieth Century. New York: Semiotext(e).

Sylvester, David. 1987. The Brutality of Fact, Interviews with Francis Bacon. London: Thames and Hudson.

Vanhanen, Janne. 2010. Encounters with the Virtual: The Experience of Art in Gilles Deleuze's Philosophy. Helsinki: University of Helsinki Press.

\section{Biography}

Stephen Zepke is an independent researcher based in Vienna. He is the author of Art as Abstract Machine, Ontology and Aesthetics in Deleuze and Guattari (Routledge, 2005) and Sublime Art, Towards a Philosophy of the Future (EUP, 2017). He is the co-editor of Deleuze, Guattari and the Production of the New (Continuum, 2008), Deleuze and Contemporary Art (EUP, 2010) (both with Simon O'Sullivan), and Art History After Deleuze and Guattari (Leuven, 2017) (with Sjoerd van Tuinen).

(c) 2017 Stephen Zepke

cc) (†) Except where otherwise noted, this work is licensed under a Creative Commons Attribution-

(cc) Non Commercial-ShareAlike 4.0 International License. 